\title{
SEEING (FROM) DIGITAL PERIPHERIES: Technology and Transparency in Kenya's Silicon Savannah
}

\author{
LISA POGGIALI \\ University of Pennsylvania \\ (D) http:// orcid.org/0000-0001-5598-261X
}

"The equipment-free aspect of reality here has become the height of artifice; the sight of immediate reality has become an orchid in the land of technology.”

-Walter Benjamin

"We don't map those," Kyale stated emphatically, gesturing to the spigot jutting out of a makeshift mud structure from which women were collecting water in plastic jerry cans. His GPS unit dangled from a cord wrapped around his wrist, and it swayed in step with his measured gait as we passed by the water point. A flicker of confusion must have swept across my face, and Kyale leaned over and whispered to me: "That water point is not by the government, but by the community. It's illegal, so we don't map it." It was nearing the second hour of our data collection expedition in Kyale's neighborhood, an informal settlement of Nairobi, Kenya, that I will call Muhimu. A few moments later, Kyale paused in front of a different water point - this one with a Nairobi City Water and Sewage Company (NCWSC) meter attached - and recorded its latitudinal and longitudinal coordinates with his GPS device. Later, taking respite from the heat of the day, he would retreat indoors to upload these coordinates to a computer using the software platform Java OpenStreetMap Editor (JOSM). By aggregating his data with those collected by other volunteer mappers over the span of a few 
months, he would help create a digital map of Muhimu; it would be the first publicly circulating map of any kind to acknowledge the settlement's existence. "It's good to be recognized; people should know the real Muhimu," Kyale told me, explaining his devotion to mapping.

That Muhimu could be known by outsiders at all was a novel idea. As one of Nairobi's informal settlements, it was considered illegally occupied; as such, its villages, roads, hospitals, and schools were depicted on government paper maps and digitized Google ones alike as a vast swath of empty space, a large blank spot. The project that Kyale was volunteering for-Muhimu Mapping Project (MMP) — was one of many techno-utopian digital mapping projects that formed in the wake of Kenya's 2007-2008 postelection violence, when politically motivated conflict led to more than 1,200 deaths and 660,000 displaced citizens. The managers of MMP — Sarah, a Canadian, and Miroslav, a Russian-believed that mapping Muhimu's infrastructure would encourage local political leaders to bring resources to the neglected area. If Muhimu's resources and needs were highlighted on digital maps, Sarah and Miroslav reasoned, the neighborhood could no longer be ignored. Bringing government attention to the settlement's wellbeing had recently also become a means to ensure its survival. The citywide displacement of so-called informal areas had become increasingly commonplace as Kenya attempted to fulfill its ambitious long-term development plan, Vision 2030, which mandated infrastructural upgrading (Dolan 2012). This plan was eerily silent about Nairobi's settlement residents, who comprised more than half of Nairobi's 3.1 million people (Amnesty International 2012). During a presentation at the Africa Geospatial Forum, an annual conference celebrating the past achievements and future possibilities of geospatial technologies in areas of governance, development, and economic growth on the continent, then director general of Vision 2030, Mugo Kibati, had stated brusquely that "Vision 2030's vision on informal settlements is to get rid of them. Plain and simple." But what was "plain and simple" about erasing more than 50 percent of the bustling capital's residents?

"The whole point of this mapping thing," Miroslav told me the first time we boarded a matatu van and journeyed from the freshly tarmacked roads of Nairobi's Central Business District to the potholed, chaotic eastern portion of the city, is "to make the invisible visible." Political recognition, according to Miroslav, followed from visually witnessing data about the neighborhood. For MMP, more information was imagined to lead to more substantial political engagement in the settlement. At the time of this interaction, I had been following the digital map- 
ping activities of Kyale and his colleagues for almost a year. After countless days spent chatting with Muhimu residents and observing their technical training and data collection, I had developed what I thought was a solid grasp of the politics of service provision in the slum. I thus interpreted Kyale's carefully calibrated mapping practice - choosing to map official water points, while deliberately leaving community ones undocumented - as a reflection of his unwillingness to disrupt the micropolitics of slum life and invite unwanted attention from the notoriously corrupt NCWSC. ${ }^{1}$ Despite these selective mapping practices, however, residents consistently justified their work by arguing, as Kyale had, that their digital maps displayed the real Muhimu. "Transparency is a good thing," Sam, another mapper, told me unequivocally when I asked him about his desire to map his neighborhood. The mappers imagined that the maps could be mobilized as visual evidence to counter negative perceptions that circulated about the area. "Muhimu's name has been tarnished," explained Peter Odondo, a mapper in his twenties. "Most people are afraid and think it's a very insecure place." Using the words real and transparent interchangeably to explain their mapping work, Kyale and his colleagues expressed faith in the maps as unmediated visual truth, on the one hand, and knowingly produced highly selective representations, on the other.

This tension at the heart of transparency discourse - that revelation is always shadowed by concealment - has been well documented by social scientists (Strathern 2000; Hetherington 2011; Mazzarella 2006; Levine 2004; MacLean 2014; Morris 2004). Less frequently considered, however, is how transparency-seeking practices are informed by the subject positions of those who produce them. This issue, I suggest, was brought to the fore by the Muhimu mappers' work. How does the mapmakers' status as urban slum-dwellers color the production and reception of the information they produce? ${ }^{2}$ By bringing attention to a group of people - the urban poor - not typically imagined to be the producers of either technology or transparency, I uncover an irreconcilable contradiction at the heart of the mapmakers' sociotechnical engagements: while mappers like Kyale attempted to strategically produce and document transparent representations, they first had to prove they had the authority to do so. The mappers thus struggled to commensurate two desires: first, to be recognized as Kenyan citizens in the face of social and political exclusion, and second, to be recognized as technical experts, whose work was legitimated only when the maps superseded the presence of those who produced them. The mappers, I argue, aimed to be visible and invisible at the same time. How were these incommensurable desires shaped through mapmakers' engagements with geospatial technologies? And what new aspirations 
and anxieties were produced in and through mapmakers' attempts to establish belonging in Silicon Savannah, a term widely used in Kenya and beyond to position the country's Information and Communications Technologies (ICT) sector as the digital technology epicenter of Africa writ large?

To answer these questions, I draw on more than two years of ethnographic research on Nairobi's emergent digital technology sector. Specifically, this article focuses on the desires and practices of a group of slum-dwellers who showed enthusiasm for geospatial technologies, which led them to join MMP. I explore how, through making their neighborhood visible through digital mapping work, the mappers also attempted to make themselves visible as technical experts. In this sense, making their physical location (Muhimu) known through mapping became a strategy to change their social location: ${ }^{3}$ as their neighborhood became legitimized, so did they themselves.

I thus suggest that while the goals of Muhimu's technologically savvy residents were partly strategic - that is, they were careful not to expose features like community water points that might cause internal conflict in their neighborhood and, as I show below, they were frequently preoccupied with generating income - these strategies were bound up with a broader desire to fashion an aspirational identity. I thus consider the digital mapping activities of Nairobi's urban poor not as purely technical operations aimed at illuminating previously invisible peoples and places, but rather, as sociotechnical practices that produced subjects and places in and through the process of depicting them. Digital maps, I suggest, are thus not merely tools whose utility can be analyzed separately from the subjects who create and use them (cf. de Bruijn, Nyamnjoh, and Brinkman 2009). Rather, they are objects whose meaning can only be apprehended when considered as part of a broader representational economy (cf. Kelty 2008; Coleman 2009; Keane 2006; Miller 2005). While producing and tinkering with digital maps cultivated aspirational identities, such practices at the same time generated unease, as the mappers feared that they would be unable to adequately capitalize on the technologies' potential. ${ }^{4}$ Residents were intensely worried that competitors with better images or more professional credentials would outpace them.

Social scientists have pointed to the socially and politically generative quality of mapmaking as key to the modern state's consolidation and assertion of power (Scott 1998; Mitchell 2002; Winichakul 1994; Anderson 1991). Through acts of classification and quantification, the colonial state produced "deep social and institutional roots" as it "multiplied its size and functions" (Anderson 1991, 169). Indeed, during the colonial era in Kenya, the British used mapmaking to regulate 
the living and working space of Africans (Cooper 1997; Elkins 2005, 16; Zelaza 1992). Today, however, despite the Kenyan state's growing interest in geospatial technologies' governmental potential, these new forms of visualization have thus far not led to new forms of surveillance (cf. Burchell, Gordon, and Miller 1991; Strathern 2000; Anderson 1991). Rather, digital mapping technologies have been primarily used in citizen-led movements to counter existing versions of state record keeping.

In focusing on how digital mapmaking was bound up with the production of personhood, I foreground the ways in which subjectivity and social relations of power inform understandings of transparency, enabling the value of information to shift. The process through which mapmakers and maps fashioned one another influenced whether the information produced - the maps themselves - would be interpreted as useless noise, credible data, or something in between. Here, pace the dominant narrative in Nairobi's techno-utopian social world, more information did not lead to more transparency (cf. MacLean 2014; Hetherington 2011). Indeed, what was at stake was the degree to which particular kinds of information became coded by various actors as transparent at all. Below I briefly discuss how digital technologies came to embody the shared dreams that animated Kenya's ambitious development plans, while at the same time they also expressed and reproduced class-based hierarchies. Next, I explore how slum-dwellers themselves narrated the relationship between geospatial technologies and visibility to understand how the mappers connected visibilization to the cultivation of expert selves. Finally, I discuss how ideologies about technology, transparency, and mediation structured beliefs about the maps and mapmakers, and how the symbolic and material qualities of the digital form alternately enabled and challenged $\mathrm{Mu}$ himu's mapmakers' self-actualization.

\section{FETISHIZING THE DIGITAL, FETISHIZING THE POOR}

Kenya's flirtation with digital technology began in the early 2000s, after the telecommunications sector was deregulated and the country's sole wireless provider, Safaricom, morphed from a state-owned subsidiary of Telkom Kenya into a private company. State-corporate partnerships, which financed Kenya's first underwater fiber optic cable to the tune of $\$ 130$ million, ensured that ICT would become a major political focus. In the years after the cable's completion in 2009, fiber-optic infrastructure linked Kenya to international communication networks, decreased the price of bandwidth, and drove foreign investment. With respect to the local market, Safaricom grew its customer base exponentially by offering 
cheap mobile phone packages and an SMS-based money-transfer system, M-Pesa. Mobile phones enabled Kenyans to circumvent the country's limited banking infrastructure and high transaction fees that barred most citizens access to formal savings plans. Safaricom became emblematic of technology's potential, as national and international press praised the company for contributing to free-market economic growth and also helping Kenya's poor save and invest in businesses. In a particularly brazen statement of support, the Economist (2008) went so far as to claim that Safaricom had probably done "more to help Kenya than decades of aid" and encouraged would-be investors that they could "pay to bet on the poor."

Stretching across 182 acres to the east of Nairobi's Central Business District, Muhimu's land is owned partially by the City Council of Nairobi and the Government of Kenya (Pamoja Trust 2009) and partially by absentee landlords, who acquired title deeds under highly ambiguous circumstances. Muhimu was also one of the worst affected areas of Nairobi during Kenya's 2007-2008 post-election violence, owing to its large population of unemployed youth, its history of protracted conflicts over scant resources, and its high degree of segregated ethnic diversity. That MMP chose Muhimu to conduct its mapping work was thus not coincidental; alongside others in Kenya's growing technology sector, the organization's founders promoted digital technology, with its supposedly neutral, equalizing digital code, as a tool to foster peace and pan-ethnic cooperation in the slum (Poggiali n.d.). MMP was one of many geospatial projects that emerged in Nairobi's informal settlements after 2008; these projects were variously organized and funded by transnational media NGOs like Internews, international development organizations like USAID and Plan International, educational institutions like Emory University, and geospatial activist groups from places as far afield as Italy and Brazil. Most mapping projects were implemented with local partners - community health workers and organizers active in the settlements. ${ }^{5}$

Maps are "close to that Internet thing, [which] people are crazy about right now," Njoroge told me, trying to explain why mapping had become so popular in Muhimu. "For us," Njoroge said, speaking about slum-dwellers like himself, "when you see a computer, you see English." We were sitting in the community center that served as the central gathering place for MMP's technical trainings and organizational meetings. The blips and bleeps of incoming instant messages in the room next door served as a fitting soundtrack for his thoughts on the symbolic significance of digital technology in the slum. While the mappers celebrated the narrative of technology-fueled success, they also had to fight continuously against the growing anxiety of being excised from it and the persistent 
reality that they were not full participants in it. Shimba Technologies' Mbugua Njihia - a member of Kenya's elite technology sector-exemplified this attitude at a presentation at the DEMO Fall 2011 conference in Santa Clara, California. He implored the audience to think of Kenya as an emerging market that had different characteristics from the United States. "Think long distances," he said. "Think poor infrastructure, but then again think opportunity" (Njihia 2011). Like the sharp business minds at Safaricom, Njihia invoked the idea that the poor could drive investment to Silicon Savannah, but that they themselves were not its authors. Rather, they were stepping-stones to others' economic growth. Njihia's comments invoke a double instance of fetishization: of technology as a magicbullet solution to the problem of poverty and infrastructural lack, and also of the poor themselves as a ground on which technological experimentation could best occur; software coders and web designers constructed the poor as the constitutive outside of Kenya's technological takeoff. ${ }^{6}$ Their views reflected a tension between what they saw as the intrinsically sociopolitically equalizing qualities of digital maps and their circulation in a milieu premised on free-market capitalism, in which ethics gave way to market calculations. In the first discourse, poverty was a technical problem to be solved, while in the latter it was an opportunity for foreign venture capitalists to grow their investments.

This discursive exclusion of the urban poor from the realm of technological production reflected both a socioeconomic and political gap that existed between the epicenters of Silicon Savannah and the informal settlements. Aside from the technologists who worked directly on mapping projects in the impoverished sections of Nairobi, coders and web designers rarely (if ever) engaged in outreach with Nairobi's urban poor. ${ }^{7}$ This lack of interest was reinforced by a material exclusion. Nairobi's technology epicenter, the iHub, a multilevel coding/social/ event space reminiscent of Google's offices in the United States, was located in the western portion of the city in the upper-middle class neighborhood of Kilimani. Here, technologically curious Kenyans were welcome to attend free catered events, such as the Google mapping party, where participants competed for prizes by adding sites to Kenya's current Google map. Outside of event times, Kenyans could use the iHub's lightning-speed wireless connection for free. Kilimani, however, was on the other side of the city from the majority of Nairobi's slums, including Muhimu, and the approximately \$1 public transport fee was prohibitively expensive for most residents. Indeed, only one of MMP's volunteers visited the iHub during my time in Nairobi. Despite the spirited interest in technology expressed by settlement residents, and the excellent technical skills exhibited by 
many of them, their access to the broader community of software coders and geospatial experts remained beyond their reach. The inclusive rhetoric of Kenya's technology sector was shadowed by its own exclusions.

\section{"YOU CAN'T JUST SIT THERE BECAUSE EVERYTHING IS COMPUTERIZED”}

The settlement residents who joined MMP were representative of the demographic that generally joined NGO projects in their neighborhoods: mostly male "youth" (aged eighteen to forty) with good English skills, limited domestic responsibilities, and diversified sources of income, which afforded them the ability to volunteer for indeterminate amounts of time and uncertain economic benefit. Michael Omolo, a thirty-three-year-old mapper who was supporting a wife and a six-year-old daughter, described obtaining income through a most unlikely combination of sources: repairing machines for pharmaceutical companies, collecting garbage, and selling rabbits. Despite spending much of their time "hustling and bustling" for money, none of the mappers were financially secure. When the creators of MMP — who lived in the United States - swooped into Nairobi for a week and called a meeting downtown to discuss the future direction of the organization, many of the mappers expressed frustration when they were not given fare for public transportation from Muhimu (approximately KSh60, or less than \$1). "Some people walked to town and back," Elisa, a mapper, told me, explaining how she and her colleagues negotiated the economic obstacle; this trip took an hour and a half each way.

Indeed, the mappers' interest in MMP was informed by their hope that it would be a stepping-stone to potential future economic opportunities. "Nowadays people have to acquire more skills and knowledge," explained Elisa, of her desire to join MMP. "Not just sit in one place. For example, say that I'm a farmer, I should [explore] other arenas such as fishing and business to add to whatever I have. . . . So I decided to join [MMP] to get knowledge for the future. You never know where your luck lies." In a socioeconomic milieu where steady, secure work was a luxury afforded to a select few, MMP was thus part of a broader employment strategy. In this respect, it was not dissimilar to other money-generating activities, such as carrying a heavy load for a construction company or attending a UNICEF training that promised a monetary stipend. "You cannot depend on one thing, you must have many avenues," Peter Odondo confirmed, echoing Elisa's comment above. As a digital technology project, however, MMP constituted a specific kind of income-generating activity: it reflected the surge of 
interest in Information and Communications Technologies for Development (ICT4D) projects more generally in Nairobi since 2008, and the sentiment expressed by young Kenyans across the class spectrum that digital technology was a pathway to a better future life. "Nowadays it's a world of technology," Elisa told me. "You can't just sit there because everything is computerized . . . you can't do things manually." Doing things manually meant failing to live up to the modernist vision invoked by digitality, and the mappers, like others in Kenya, did not want to be left behind.

Indeed, in addition to slum-dwellers, Kenyan and expatriate software developers, web designers and bloggers, and the Kenyan state all discussed new technologies as a harbinger of Kenya's socioeconomic development. The technologies' meaning was deeply influenced by their material form, which caused their advocates to perceive them as unmediated by human action. Witness Lands Cabinet Secretary Charily Ngilu's statement regarding the Lands Ministry's decision to digitalize the Lands Registry: "I must admit that all has not been well at the Lands Ministry because of cartels, which engage in shady deals that have defrauded Kenyans of millions of shillings. That will soon end once we digitize all records" (Mbaka 2013). Digitization, in this commonly articulated discourse, was understood to solve endemic bureaucratic corruption because of its powers of immediation, an issue I discuss further below. Muhimu's mappers echoed this discourse, expressing in more concrete terms the potential political possibilities inherent in digitally manufactured visibility: "Mappers can say 'this is a children's playing ground' and put it on a [digital] map," Njoroge, MMP's community coordinator, told me. "For a government to put a playground where there is a playground, it has to go through a legal process. And in the process somebody comes in and manipulates [the situation], and grabs the land." Both Ngilu and Njoroge imagined that the speed and immediacy of digital technology would forestall the malevolent activities considered an everyday part of social and political life in Kenya. Immanent to the digital form, in other words, were notions of ethics, truth, and prosperity, qualities that exceeded the technologies' seemingly banal function on the streets of Muhimu, that is, as part of a diversified economic strategy.

\section{PRODUCING EXPERTISE}

"This is what you need to know," Miroslav said, pointing to a sheet of paper with "NEED TO KNOW" scrawled at the top in black magic marker; he had taped it to the bright blue walls of the community center in Muhimu where MMP 
held regular meetings. Underneath it, he had written: "1. GPS SETUP (tracks, time, map, waypoints, units); 2. DATA TRANSFER (GPS Babel); 3. JOSM (editing; uploading, downloading)." This was day one of three days of testing the mappers on their knowledge of geospatial technologies. Those who passed the test would receive printed certificates attesting to their expertise and would be invited to continue volunteering for the organization. Those who failed would have to retest, and if unsuccessful, would be asked to leave. One by one, Miroslav called each of the mappers outside the organization's headquarters; they stood abutting a large pile of trash that had been caked into the ground by the ravages of weather and the continuous imprint of residents' footsteps. The mappers answered the questions as best they could, occasionally raising their voices over the brief snippets of reggaeton that punctured the air from passing cars. The testing ended inside, with the mappers using one of three laptops, property of MMP, to upload points using GPS Babel, and plot them on a map using JOSM. Through such testing practices, MMP constructed digital mapping as an expertise-producing activity.

Months later, Miroslav and Sarah invited the mappers to an elaborately staged party at a restaurant not far from Muhimu. After noshing on mbuzi choma (roasted goat meat) and Tusker, the local beer, they called each of the mappers to the front of the space to receive their printed certificates, which stated that they were "proficient in GPS data collection, basic editing with JOSM, and OpenStreetMap data entry." Crucially, these certificates also displayed the insignia of both MMP and a large health-related NGO that had sponsored the trainings. The mappers proudly displayed their certificates, and all parties paused to ensure that the multiple cameras documenting the event captured the exchange of documents, hugs, and hearty handshakes. The certificates substantiated what the day of testing had initially suggested - that the mappers were now geospatial experts. As their desire to be photographed made evident, the mappers reveled in this status.

"Nowadays . . . [there are many people] teach[ing] computer lessons to students, [but] they can't award you a certificate, so you can't be recognized anywhere like you know anything about computers," Elisa said, comparing MMP's training program to others she had encountered in the area. Such comments revealed certificates to be one pathway to recognized expertise, which promised the possibility of future work and a better life. Emmanuel, another mapper, concurred: 
There was some NGO . . . dealing with HIV status. They wanted guys who had reached a certain level in school. But when I showed them the certs [certificates] that I had, they took me for work. They said, 'Ah, this guy has been participating in many events, so let's go with him.' My level of education, they didn't see it as law, but what I've been doing to improve myself, [they saw it as] vital.

Emmanuel's story suggests that the visibility of the certificate made the self visible in a new way. That is, it conferred expertise that enabled one to bypass more traditional channels to employment, such as education. Being able to show the certificate to others, to have them recognize it, was crucial for this demonstration of expertise. The mappers' preoccupation with receiving the certificates makes clear that despite the pervasive discourse that associated digitality with unmediated truth, the mappers were aware that becoming proficient in digital mapping was not a channel unto itself; the digital maps were mediated by another document, which had been authorized by NGOs.

Mappers themselves linked the practice of making Muhimu visible to two main outcomes: the ability to recalibrate sociopolitical relations with neighborhood authority figures, and the ability to make social connections that could lead to work. Indeed, the digital served as a shared grammar through which local government leaders and mappers could position themselves as equals in Kenya's race toward modernization. "Does mapping increase transparency in Muhimu?" I asked one mapper, Maurice.

Yes, it made a big awareness . . . the mapping did a very unique thing. The DO [district officer], the chiefs . . they are now starting to trust the youth. [We took] the first map to the DO and he asked, "Who did this?" We said to him, "we ourselves did this." He said, "you are doing a very good idea. Even those mzees of kijijis [elders in the villages] who are saying you are thieves, I cannot believe it from now." [They believe] that [the youth] can do something.

Here, the technological expertise conferred by transparency-seeking effected a political shift: their status vis-à-vis local government improved.

In his research on campesinos' struggle to claim land amid sweeping political and economic changes in contemporary Paraguay, Kregg Hetherington (2011, 151) suggests that retaining control over the circulation of documents related to land titling had political consequences more profound than mining the information 
contained within them. Though the maps in Muhimu were consistently referred to by mappers and project managers alike as evidence to improve service provision in the slum, government officials rarely, if ever, used the maps' content in urban planning or service distribution. Yet the maps hung on the walls of the offices of district officers and local chiefs, the only documents displayed save for tattered calendars marking the passage of time. The documents' generative effect, I suggest, was not to inspire civil servants and political figures to assume their formal duties as democratically elected representatives, as Miroslav and Sarah envisioned, but rather to signal that they understood and formed part of the world in which the maps circulated, both symbolically and materially (see Larkin 2013). That the maps, pointillist conglomerations of dots and dashes, had traveled through the cavernous heart of a computer before transmogrifying into the banal, tactile documents familiar to government officials everywhere only underscored the extent to which "the medium of objectification matter[ed]" (Miller 1987, 129) in this case. Indeed, the maps' close affiliation with the computer, which Njoroge, Ngilu, and others purported would translate human folly and malfeasance into sets of quantifiable, and therefore neutral and objective, standards, made them desirable. Given Muhimu's recent violent history, residents and foreigners alike contrasted cold, calculated computer knowledge with what the local press had characterized as an excess of affect that led to the 2007-2008 violence.

When the chiefs and DOs prominently showcased the maps, they signaled their convergence (see Mazzarella 2006) with those they were expected to govern, slum-dwellers, without having to substantively engage with them, implement policies, or distribute services. Indeed, Njoroge's eyes lit up on recounting how a DO or chief had taped a printed map to his office wall, corroborating Mark's account that the maps caused local leaders to reimagine the youth of Muhimu in a positive light. Furthermore, through including the maps, technical objects associated with modern, prosperous Kenya, local government officials also sent the message that they were custodians of technical knowledge. In this way, the maps served not "as the end point, but as the site of possibility, not a store of information as a static thing but as a tool for making a political effect" (Hetherington 2011, 166). For local political authorities and the mappers themselves, transparency was not a presumed effect of the content of the maps - more or better information - but rather an imagined by-product of their material and symbolic association with digitality. 


\section{TRANSPARENCY, TECHNOLOGY, AND EXPERTISE}

Transparency emerged as a major discourse of governance in Kenya in the early 1990s, amid shifting global politico-economic configurations in the postCold War era. No longer dependent on Kenya strategically, donors, whose aid contributed nearly 30 percent of the GDP (Throup and Hornsby 1998), began focusing their attention on economic and governance reforms. In 1991, for example, the Paris Group of donors threatened to withhold \$350 million in aid unless President Daniel arap Moi deregulated the economy and opened its budgetary data to outside scrutiny (Githinji and Holmquist 2011, 12; World Bank 1991).

While used as a rallying call by the plethora of Kenyan NGOs that formed in the 1990s, transparency gained new traction as a political buzzword in the early 2000s. It reemerged with ICT4D, an ideological framework that presumed poverty could be solved by granting the poor access to technology. The framework, as William Mazzarella (2010, 785) argues in a global context, "was sold as a reconciliation between neoliberal capitalism and the interests of the poorest people in the world." Driven by quantifiable calculations and rapid speed, Kenya's urban coders and web designers viewed technologies as magical vectors of transparency, which promoted both democracy and market efficiency by bringing large amounts of information to a broad scope of people instantaneously (cf. Dean 2002; Mazzarella 2010). "We are all part of a sea change in news and information flow and transparency," commented Erik Hersman (2009), the cofounder of the Kenyan digital mapping platform Ushahidi and founder of the iHub. "The barriers are finally so low that anyone can tell their story, and the whole world can see it. There is no stopping this change in information dynamics, there is only harnessing it in ways that add more value. . . The more data that is collected, the less chance that bad data can have an adverse effect."

Social scientists (e.g. Mazzarella 2006; Hetherington 2011) have criticized ICT4D discourse for joining a functionalist argument about poverty with a political one about the failures of the state. If given unfettered access to the information economy, ICT4D_ exemplified by Hersman's comments — presumes, individual citizens can both lift themselves out of poverty and throw off the shackles of dictatorial regimes (Hetherington 2012, 242). Instead of tackling inequality, it produces "individualistic, market friendly, and measurable entities" (Ballestero S. $2012,160)$ and has thus been described as the ethical alibi of neoliberal governance (Marcus and Powell 2003; West and Sanders 2003; Mahmud 2012). Such criticism is helpful in exposing transparency and its attendant projects as ideologies. Yet in 
treating transparency as a smokescreen that conceals hidden machinations of power, these critiques elide the concrete cultural practices and social relations through which transparency discourse is produced (Strathern 2000; Mahmud 2012); transparency is instead imagined to act on, yet stand above, social life (cf. West and Sanders 2003). These critiques also implicitly presume that there is a fixed relationship between the purported producers of transparency (e.g., NGO workers, state bureaucrats, software developers) and those who, the wool pulled over their eyes, are (falsely) assumed to benefit from it (e.g., the uneducated and/or poor). The ethnographic data I have presented here resists such a reading by showing that, like the archetypal elite transparency-seeking subject, slumdwellers, the so-called benefactors of transparency-producing technologies, are also invested in transparency discourse and strategically enact transparency-seeking practices. Thus my research interlocutors in Muhimu compel me to consider transparency discourse as a form of claim-making about technological expertise, which indexes a range of other desires, including economic mobility and political recognition. While critics might suggest that this focus elides how powerful actors exploit the economic depravity of slum-dwellers by coercing them to use hegemonic discourse, I suggest that these very discourses "can be deployed against the exclusions and inequities that have historically been associated with them" (Cooper and Stoler 1997, 35).

Marilyn Strathern's (2000) research on social audit in British higher education rigorously explicates the schism between transparency as an ideal and as a culturally produced practice. She explores how both academics and auditors tolerate the incongruity that the audit produces - between representation and reality, visibility and knowledge - to advance a shared abstract value of institutional transparency. By challenging state-authored cartographic depictions of Muhimu, in which the area is formally portrayed as a piece of land devoid of people and place, the mappers reconfigured existing representations of territory and authority. In that Muhimu mappers' work was driven by the desire to assess, question, and correct the cartographic practices of the state, we can think of them as auditors in their own right. They claimed, through their work, to produce a transparent representation of their neighborhood, which sharply contrasted with the government's version. However, while transparency was an abstract value that guided their work, it was not the presumed effect of that work. Like the education auditors in Strathern's research, the digital mappers, too, struggled with the incommensurability of representation and reality, abstract ideology and technical practice. Yet because of the mappers' differential socioeconomic position and 
their desire for sociopolitical visibility, the information produced through their transparency-seeking work was received and processed differently by its intended audience.

Foremost, the educators' authority as auditors was never questioned. The auditing process, I suggest, was driven by a desire for what William Mazzarella (2006, 476) calls the "politics of immediation"; that is, "a political practice that, in the name of immediacy and transparency, occludes the potentialities and contingencies embedded in the mediations that comprise and enable social life." Mazzarella points out that technologies are externalizations of the mediations that constitute sociality; they are material forms whose effect is to reduce the irreducibility of everyday experience. ${ }^{10}$ Following this rationale, in Strathern's case, audit is a technology that succeeds in its mission to objectively assess educator performance because it presumes to rely on formalized standards, as opposed to subjective human action. Thus its logic relies on a denial of the social practices and subjective decisions necessary to enact it. The auditors succeed because their presence as acting subjects fades into the background, allowing the audit to take center stage.

In the case of Muhimu, widespread faith in the digital form, which technology enthusiasts believed would eliminate graft by removing human action from the process of monitoring, led many to claim that digital maps offered a more exact optic of place than ever before. However, unlike in Strathern's example, Muhimu's mappers had yet to be acknowledged as authoritative auditors; they were socially invisible. Indeed, while the mappers attempted to both produce and document transparent representations to bring sociopolitical attention to themselves and their neighborhoods, they first had to prove they had the authority to do so.

As a material expression of the politics of immediation, the maps expunged human presence from the narrative of their creation; they signified an absence of the social relations of mundane bribery that lubricated the circulation of resources in the slum. At the same time, because Muhimu residents physically brought paper versions of the maps to the district officers' and chiefs' offices, the socially mediated quality of their production could not be denied. In that powerful leaders in Muhimu chose to display the maps, these digital products transformed slumdwellers into subjects with the capacity to produce expertise, a heretofore unrealized capability. "Before, the elders just thought youths were doing drugs and hustling," Kyale told me. "Now they see we are doing good things too." The slum-dwellers' potential credibility as experts emerged as an effect of the maps, 
simultaneously indexing digital fetishism and a persistent (post)colonial faith in the political authority communicated through paper documents. Beyond the sociopolitical world of Muhimu, however, settlement residents found it difficult to leverage their expertise and make the information they produced matter.

Owing to a dearth of computers and an unreliable electricity supply in Muhimu's offices, these maps lived offline, separated from the computers that made them possible. Over the course of my time in Muhimu, their edges began to fray, and their borders slowly changed from white to yellow. Away from the radiant light of digital code, their symbolic power slowly weakened as the maps' material fragility began to mimic the insecurity of the settlement and its residents (cf. Larkin 2013). Indeed, for the residents of Muhimu, the maps embodied the duality of precarity and promise that characterized Kenya's technological takeoff. The maps were a potent metaphor for the uphill battle the mappers fought when they attempted to shift their subject positions through their engagements with digital technology. In their struggle to become socially visible, their status as technical experts and the credibility of their digital data were thrown into question. How could data that was so obviously mediated be trusted? For the mappers, the semiotic-material economy of computers, like the physical space of the iHub, proved to be just out of reach.

\section{THE TEMPORALITY OF TECHNOLOGY}

If speed was a capacity of digital code, then immediation was not only an ideology driving the mapping work but also a potential material capacity of the maps. "If the community is the one who is mapping their own area, they legitimize a space," Njoroge told me. According to him, digital maps' speed made them a viable solution to bureaucratic inefficiency and corruption. As I mentioned earlier, by codifying the presence of a playground on a digital map, the mappers could prevent others from grabbing the land during the lengthy legal process required to obtain an official title. Time, for Njoroge, was a negative unit that invited the possibility of nefarious action, a period during which ruthless outsiders could wrongfully claim land that did not belong to them.

Njoroge's concerns elucidated a world of law and paper, one structured around temporal gaps that encouraged the breach between representation (a legal land-use document) and reality (the act of land grabbing) to deepen. Njoroge explained digital technology - frequently discussed by scholars as a malleable, disembodied form (e.g., Mitchell 1996) — as a stable anchor in this uncertain world. It not only alleviated the anxieties slum-dwellers felt around government 
officials' potentially nefarious plans, but it also instilled new hope that the slumdwellers might finally be able to outwit them. "When you have people put it on digital," Njoroge continued, "there's something to fall back on, to say, 'in 1980, [the land] was like this.'” Here, Muhimu's digital maps physically embodied the immediacy they were presumed to bring about, merging the ideological and the material into a cohesive narrative. In this case, the political potential of the maps was tied to digital code's ability to visualize a situation quickly.

Digital technologies' speed was not always a positive attribute for settlement residents, however; in fact, it often generated new fears about potentially being left behind. "It's high time we take advantage of [the fact that much of the world is not mapped]," Ronald, one of the most technically proficient mappers of the group, relayed to me, with a sense of urgency in his voice. "We are the pioneers of [digital mapping]. And we should grab that opportunity to be recognized. We should expect competition from organizations like Google. Google are coming in. If we are not creative, we will be locked out of all these things, and our idea will be stolen," he continued, gesturing to the narrow window of time they had before their own talents would be eclipsed by outsiders with more established credibility.

One day, frustrated, Njoroge told me that USAID had recently initiated a digital mapping project in Muhimu. They wanted geospatial experts to mark properties where they were planning to establish Voluntary Counseling and Testing clinics, part of a larger project to combat HIV. Previously, USAID had funded MMP's technical training, but they did not approach any of Muhimu's residents about the mapping project. "If we were working in partnership with them," Njoroge lamented, "we could easily have done the mapping of the houses for them in a very professional and a very good way." The problem he identified was that, despite their technical expertise and cultural familiarity with the area, USAID failed to take the mappers seriously.

Ronald and his peers had already experienced such competition firsthand. An established Muhimu community organization was "hijacking [their] idea," Ronald told me. Rather than involve the mappers in their work, they hired two people from Kenya Polytechnic, a local university, "to do the GIS. Soon they will be producing their own maps with a platform," Ronald bemoaned. He started rattling off ideas for new platforms, one of which involved tracking vulnerable children in the neighborhood. "It's a high time we start embracing other new technologies," he said, gesturing to one of the ways the mappers could respond to the competition. Here, Ronald revealed the uneven geography of power in 
which the digital maps circulated. Rather than evening out the technological terrain, mappers' sociotechnical work created a pervasive sense of disquiet as they realized that their technical capabilities and the information they collected was far from enough to secure their future.

Digital maps' material capacity for speed gestured to the broader temporality of development itself, and of Vision 2030's ambitious goals. For settlement residents, the gleaming surfaces of high-rise luxury apartments being erected all over town, and the expansive highways - sturdy monuments to progress built at breakneck speed by Chinese and Japanese contractors - signaled both the abstract promise of a grander future and the terrifying threat of impending physical eviction, in which racing ahead always also implied leaving something, or someone, behind. While Nairobi's ICT4D advocates championed digital maps in part because of their association with an apolitical world of numbers and code, Ronald's comments show how establishing transparency was a profoundly political activity. At its heart was a struggle over not merely how the neighborhood would be represented, but also over who would have the opportunity to make the neighborhood visible. These moments of tension highlight the degree to which mappers' subject positions informed both how they strategically mobilized the technologies and, just as crucially, how the technologies shaped them, invigorating them with both exciting new dreams and nerve-wracking nightmares.

\section{CONCLUSION: Seeing (from) Digital Peripheries}

Technology in its many guises has long been touted as part of the solution to Africa's problem of so-called underdevelopment. The moralizing missions of the colonial era, for example, figured Africans as peoples whose dangerous proximity to nature could be radically transformed through the technological advances of the modern world; the (religious) book and the map became crucial elements for effecting such changes. Electric lights and roads, water taps and bridges expressed the contradictions of colonial governance in their very materiality; these technologies' conspicuous presence in (some) Africans' everyday lives communicated both the accessibility of modernity and the political costs that accompanied it (Larkin 2008). The policy literature of powerful institutions such as the World Bank has also framed debates about technology in postcolonial Africa, discursively constructing African poverty as a technical, rather than a political or a structural, problem (Ferguson 1990). Read in the context of this history, one could argue that Kenyans' fetishization of the digital as an index of the modern represents nothing more than a current iteration of familiar colonial logics. 
Yet the digital in Nairobi was not merely a symbol of modernity; it was also a material form that shaped social life, subjectivity, and understandings of expertise. As a new way of seeing (Berger 1972), digital maps enabled Muhimu residents to produce self-representation, rather than relinquish it to a negligent or oppressive state, or to foreign development workers. ${ }^{11}$ This speaks to the new political capacities introduced by ICTs and the institutional mediators such as MMP that have emerged to provide a means for slum-dwellers to engage with them. By weaving a political argument about visibility, recognition, and belonging into the spaces between their strategically collected GPS coordinates, the mappers used technologies to challenge the Kenyan state and elite technology sector's discursive separation of politics and technics.

However, the channels for sociopolitical engagement carved by these new technologies were not unobstructed. Just as submarine fiber-optic cables can be cut and rendered inoperative by vandals, bringing communications networks to a grinding halt, information in Silicon Savannah, too, can be intercepted, rerouted, or impeded. To understand how and why, we must consider transparency as a claim about expertise; it can be embraced or dismissed, trusted or not. In $\mathrm{Mu}-$ himu, being able to see the neighborhood through the eyes of its residents was contingent on not only the mappers' relative adeptness at framing that information but also on a high degree of trust, what Rosalind Morris (2004) calls "intimacy," between representer and observer. ${ }^{12}$ Observers had to actively ignore the secrets that transparency-seeking practices attempted to conceal (as with Kyale's mapping activities, mentioned at the outset).

Nairobi's techno-utopian discourse implies that digitality itself makes data credible. What the story I have told suggests, however, is that the politics of seeing is inextricably entangled with the subjects and technologies that create the possibility of the picture. The mappers found themselves in an unfortunate double bind: their desire for visibility and recognition in the face of sociopolitical exclusion became a liability in their struggle to change their subject position through digital mapmaking. In this case, the socioeconomic position of Muhimu's mappers profoundly informed the perceived credibility — or lack thereof — of the information they produced. At the same time, their dream of being recognized as legitimate technical experts, a dream activated by their engagements with geospatial technologies, became a site of struggle, as they experienced both internal and external competition in their uphill battle to convince outsiders of their expertise. 
Recent anthropological work has demonstrated acutely how marginalized groups have been included in and excluded from narratives of national technological progress and promise (Burrell 2012; Larkin 2008; Horst and Miller 2006; McIntosh 2010). This article contributes to that dialogue, while also exploring how marginality can be reinforced through the very techno-utopian discourses to which the urban poor aspire to belong. In celebrating the digital as a vector of unmediated truth, slum-dwellers also worked to effect their own exclusion, raising questions about the relations of power that structured all aspects of data collection and representation. In Muhimu, the digital form cannot be extracted from dreams about development and expertise, practices of transparency-seeking, and perceptions of truth, which, for the neighborhood's residents, both generated and denied access to the promises of Silicon Savannah. The example I present here thus indexes not a disjuncture between techno-utopian ideology and the lived reality of Nairobi's urban poor, but rather a dense entanglement. It suggests that future ethnographic attention should focus not only on how new media technologies generate novel social relations or economic opportunities at the margins but also on how they produce new explanatory models that both precipitate and conceal relations of inequality. To see the inequalities (re)produced through technological imaginaries and sociotechnical engagements, we must analyze new media technologies as both potential vectors of sociopolitical recognition and as battlegrounds on which the urban poor's claims to transparency are affirmed or ignored, heeded or disregarded.

\begin{abstract}
This article focuses on how the recent proliferation of digital technologies in Nairobi, Kenya - a place many refer to as Silicon Savannah - is shaping the aspirations and anxieties of the city's poor. Taking as its point of departure an NGO project that enlisted settlement residents to digitally map their own neighborhood, I explore how geospatial technologies came to embody the shared dreams that animated Kenya's ambitious development plans and became implicated in debates about expertise, transparency, visibility, and truth. In particular, I discuss how utopian ideologies about technology, transparency, and mediation structured beliefs about the maps and mapmakers, and how the symbolic and material qualities of the digital form alternately enabled and challenged settlement residents' self-actualization. By foregrounding the ways in which subjectivity and social relations of power inform understandings of transparency, I suggest that settlement residents invoked transparency discourse as a form of claim-making about technological expertise; through making their neighborhood visible through digital mapping, the mappers also attempted to make themselves visible as technical experts. In their struggle to become socially visible, however, the
\end{abstract}


mapmakers' status as technical experts was thrown into question. I argue that to see the inequalities (re)produced through technological imaginaries and sociotechnical engagements, we must analyze new media technologies as both potential vectors of sociopolitical recognition - that is, as technologies that make social relations of power visible - and as battlegrounds on which the urban poor's claims to transparency and expertise are affirmed or ignored, heeded or disregarded. [media; technology; transparency; expertise; development; Kenya]

\section{NOTES}

Acknowledgments This article draws on more than two years of ethnographic research in Nairobi, Kenya, which was funded by the National Science Foundation's Doctoral Dissertation Improvement Grant (Award no. 1023337), the Social Science Research Council's International Dissertation Research Fellowship, the Wenner-Gren Foundation for Anthropological Research's Dissertation Fieldwork Grant, the Fulbright-Hays Doctoral Dissertation Research Abroad program, and the Department of Anthropology at Stanford University. I thank all of these institutions, whose generous support enabled me to plant roots in Kenya and to explore my research questions deeply and broadly. I am also grateful to the Program on Democracy, Citizenship, and Constitutionalism at the University of Pennsylvania - in particular to Rogers Smith, Michael X. Delli Carpini, and Greg Urban - for giving me the necessary time and space to complete this article. I presented versions of this piece at the American Ethnological Society Spring Conference in Boston, the annual meeting of the American Association of Geographers in Chicago, the Nanotechnologies for Development conference at Maastricht University in Brussels, and the annual meeting of the American Anthropological Association in Washington, DC. I am particularly grateful for the incisive comments provided on drafts of this article by Hannah Appel, James Ferguson, Kregg Hetherington, Becca Jensen, Sarah Ives, Dillon Mahoney, Bruce O’Neil, Jessica Ott, and Sylvia Yanagisako. The editorial collective at Cultural Anthropology and the anonymous reviewers improved this article greatly, and I thank Dominic Boyer in particular for his patience and encouragement throughout the revision process. Of course, my deepest debt is to the countless people who shared their worlds with me in Kenya; they continuously enlivened the connections between research and everyday life.

1. The Nairobi City Water and Sewage Company (NCWSC) provides water to Muhimu residents at metered public taps. Locals commonly reroute the water to set up their own free water points, like the community one Kyale left unmapped. These points are often controlled by neighborhood cartels, which interrupt the water flow and sell it to residents at a steep profit.

2. I use the term slum-dweller deliberately; first, it was how my interlocutors in Muhimu self-identified (excepting one mapper, who referred to Muhimu as "the ghetto"). Second, this self-identification was bound up with their frustrations about their failure to be recognized as technical experts by outsiders such as politicians, civic leaders, and NGOs.

3. Here, I distinguish knowability from legibility.

4. This does not so much index the power of new technologies to signify fantasies of progress at certain moments (for instance, when initially created) and feelings of abjection at others (for instance, when they break down or decay) (e.g., Larkin 2008, 2013; Kaika and Swyngedouw 2000). Rather, it highlights how slum-dwellers' lived experience of social precarity informed their affective relationship to new technologies.

5. Despite the settlement's illegal status and corresponding lack of an official map, then, Muhimu was nevertheless heavily governed, as it was an important node in transnational networks of care and aid, as well as of resource and knowledge extraction (see Ferguson 2006, 40; Ferguson and Gupta 2002).

6. Of course, corporations do not hold a monopoly on fetishizing the poor. Academics 
and NGOs have long celebrated poor peoples' creative acts of bricolage in the face of dire economic circumstances (e.g., Koolhaas et al. 2000); this focus on the poor's alterity advances a politics that obscures the structural violence and institutional relations of power that create and sustain inequality.

7. On most digital mapping projects, digital coders and development practitioners performed different roles; the former hunkered down at the iHub to produce new software, while the latter administered technical training directly to settlement residents.

8. While anthropologists have pointed out that enthusiasm for digital technology in Kenya is not universal (McIntosh 2010; Mahoney 2009), in the capital city of Nairobi, it is extremely widespread. In my more than two years of fieldwork between 2010 and 2013, I rarely heard anyone speak of it negatively. I attribute this in part to the fact that my research subjects — both the urban poor and elite - were involved in technology projects. Yet I heard similar enthusiasm expressed colloquially by friends, taxi drivers, service workers, and civil servants.

9. The iHub created an M-Governance project in September 2011 with the intent to "evaluate how mobile phone technology [could] be used to improve Kenyan governance, especially in enhancing transparency through access to water information, service charters and effective communication amongst the different stakeholders" (iHub Research n.d.). It hoped to replicate this project in other sectors, including education, health, and infrastructure.

10. In a similar vein, recent anthropological scholarship has drawn attention to the material mediations of infrastructure, highlighting how citizenship and the public sphere are produced in and through the tangible world of pipes and grids as much as through the discourse and publicity foregrounded in liberal conceptions of political life (Anand 2011; Appel 2012; von Schnitzler 2013).

11. Of course, this does not mean that the representations Muhimu residents produced were unmediated by such actors. Nevertheless, the maps arguably conferred the possibility of greater autonomy and control over one's image than residents had previously experienced.

12. This is a suggestion also made in the critical accounting literature on the social power of numbers (e.g., Bloomfield and Vurdubakis 1997).

\section{REFERENCES}

Amnesty International

2012 "Speaking up from the Slums." News article, April 24. http:// www.amnestyusa.org/news/news-item/speaking-up-from-the-slums.

Anand, Nikhil

2011 "Pressure: The PoliTechnics of Water Supply in Mumbai." Cultural Anthropology 26, no. 4: 542-63. http://dx.doi.org/10.1111/j.1548-1360.2011.01111.x.

Anderson, Benedict

1991 Imagined Communities: Reflections on the Origins and Spread of Nationalism. Revised edition. London: Verso.

Appel, Hannah C.

2012 "Walls and White Elephants: Oil Extraction, Responsibility, and Infrastructural Violence in Equatorial Guinea.” Ethnography 13, no. 4: 439-65. http:// dx.doi.org/10.1177/1466138111435741.

Ballestero S., Andrea

2012 "Transparency in Triads." PoLAR: Political and Legal Anthropology Review 35, no. 2: 160-66. http://dx.doi.org/10.1111/j.1555-2934.2012.01196.x.

Berger, John

1972 Ways of Seeing. London: Penguin.

Bloomfield, Brian P., and Theo Vurdubakis

1997 "Visions of Organisation and Organisations of Vision: The Representational Practices of Information Systems Development." Accounting, Organizations and Society 22, no. 7: 639-68. http://dx.doi.org/10.1016/S0361-3682(96)00024-4. 
Burchell, Graham, Colin Gordon, and Peter Miller, eds.

1991 The Foucault Effect: Studies in Governmentality. Chicago: University of Chicago Press.

Burrell, Jenna

2012 Invisible Users: Youth in the Internet Cafés of Urban Ghana. Cambridge, Mass.: MIT Press.

Coleman, Gabriella

2009 "Code Is Speech: Legal Tinkering, Expertise, and Protest among Free and Open Source Software Developers.” Cultural Anthropology 24, no. 3: 420-54. http:// dx.doi.org/10.1111/j.1548-1360.2009.01036.x.

Comaroff, Jean, and John L. Comaroff

2011 Theory from the South: Or, How Euro-America Is Evolving Toward Africa. Boulder, Colo.: Paradigm.

Cooper, Frederick

1997 From Slaves to Squatters: Plantation Labor and Agriculture in Zanzibar and Coastal Kenya, 1890-1925. London: Heinemann.

Cooper, Frederick, and Ann Laura Stoler, eds.

1997 Tensions of Empire: Colonial Cultures in a Bourgeois World. Berkeley: University of California Press.

De Bruijn, Mirjam, Francis Nyamnjoh, and Inge Brinkman, eds.

2009 Mobile Phones: The New Talking Drums of Everyday Africa. Bamenda, Cameroon and Leiden: Langaa and African Studies Centre.

Dean, Jodi

2002 Publicity's Secret: How Technoculture Capitalizes on Democracy. Ithaca, N.Y.: Cornell University Press.

Dolan, Gabriel

2012 "Evictions the Biggest Legacy of Government." The Daily Nation, October 26.

Economist

2008 “Africa Calling.” June 5. http://www.economist.com/node/11488505.

Elkins, Caroline

2005 Imperial Reckoning: The Untold Story of Britain's Gulag in Kenya. New York: Henry Holt.

Ferguson, James

1990 The Anti-Politics Machine: "Development," Depoliticization, and Bureaucratic Power in Lesotho. Minneapolis: University of Minnesota Press.

2006 Global Shadows: Africa in the Neoliberal World Order. Durham, N.C.: Duke University Press.

Ferguson, James, and Akhil Gupta

2002 "Spatializing States: Toward an Ethnography of Neoliberal Governmentality." American Ethnologist 29, no. 4: 981-1002. http://dx.doi.org/10.1525/ ae.2002.29.4.981.

Githinji, Mwangi wa, and Frank Holmquist

2011 “Transparency Without Accountability: The Case of Political Reform in Kenya.” Economics Department Working Paper Series, no. 127. Amherst, Mass.: University of Massachusetts, Amherst. http://scholarworks.umass.edu/ econ_workingpaper/127.

Hersman, Erik

2009 "Ushahidi's Anniversary and Future." WhiteAfrican, January 8. http:// whiteafrican.com/2009/01/08/ushahidis-anniversary-and-future.

Hetherington, Kregg

2011 Guerrilla Auditors: The Politics of Transparency in Neoliberal Paraguay. Durham, N.C.: Duke University Press.

2012 "Agency, Scale, and the Ethnography of Transparency." PoLAR: Political and Legal Anthropology Review 35, no. 2: 242 47. http://dx.doi.org/10.1111/j.15552934.2012.01201.x. 
Horst, Heather A., and Daniel Miller

2006 The Cell Phone: An Anthropology of Communication. London: Berg.

iHub Research

n.d. "Spider M-Governance." Project description. https://research.ihub.co.ke/ pages/spider.php.

Kaika, Maria, and Erik Swyngedouw

2000 "Fetishizing the Modern City: The Phantasmagoria of Urban Technological Networks." International Journal of Urban and Regional Research 24, no. 1: 120Keane, Webb 38. http://dx.doi.org/10.1111/1468-2427.00239.

2006 "Signs Are Not the Garb of Meaning: On the Social Analysis of Material Things." In Materiality, edited by Daniel Miller, 182-205. Durham, N.C.: Duke University Press.

Kelty, Christopher M.

2008 Two Bits: The Cultural Significance of Free Software. Durham, N.C.: Duke University Press.

Koolhaas, Rem, Stefano Boeri, Sanford Kwinter, Nadia Tazi, and Hans Ulrich Obrist 2000 Mutations. Barcelona: Actar.

Larkin, Brian

2008 Signal and Noise: Media, Infrastructure, and Urban Culture in Nigeria. Durham, N.C.: Duke University Press.

2013 "The Politics and Poetics of Infrastructure." Annual Review of Anthropology 42: 327-43. http://dx.doi.org/10.1146/annurev-anthro-092412-155522.

Levine, Amy

2004 "The Transparent Case of Virtuality." PoLAR: Political and Legal Anthropology Review 27, no. 1: 90-113. http://dx.doi.org/10.1525/pol.2004.27.1.90.

MacLean, Ken

2014 "Counter-Accounting with Invisible Data: The Struggle for Transparency in Myanmar's Energy Sector.” PoLAR: Political and Legal Anthropology Review 37, no. 1: 10-28. http://dx.doi.org/10.1111/plar. 12048.

Mahmud, Lilith

2012 "In The Name of Transparency: Gender, Terrorism, and Masonic Conspiracies in Italy.” Anthropological Quarterly 85, no. 4: 1177-1207. http://dx.doi.org/ 10.1353/anq.2012.0054.

Mahoney, Dillon

2009 "The Art of Connection: Negotiating the Digital Divide in Kenya's Curio Industry.” PhD dissertation, Rutgers University.

Marcus, George E., and Michael G. Powell

2003 "From Conspiracy Theories in the Incipient New World Order of the 1990s to Regimes of Transparency Now.” Anthropological Quarterly 76, no. 2: 323-34. Mazzarella, William http://dx.doi.org/10.1353/anq.2003.0027.

2006 "Internet X-Ray: E-Governance, Transparency, and the Politics of Immediation in India.” Public Culture 18, no. 3: 473-505. http://dx.doi.org/10.1215/ 08992363-2006-016.

2010 "Beautiful Balloon: The Digital Divide and the Charisma of New Media in India." American Ethnologist 37, no. 4: 783-804. http://dx.doi.org/10.1111/j.15481425.2010.01285.x.

Mbaka, James

2013 "Lands Ministry to Digitise Records, Says Charity Ngilu." The Standard, September 3. http://www.standardmedia.co.ke/?articleID=2000092628\& story_title=lands-ministry-to-digitise-records-says-charity-ngilu. 
McIntosh, Janet

2010 "Mobile Phones and Mipoho's Prophecy: The Powers and Dangers of Flying Language.” American Ethnologist 37, no. 2: 337-53. http://dx.doi.org/10.1111/ j.1548-1425.2010.01259.x.

Miller, Daniel

1987 Material Culture and Mass Consumption. New York: Blackwell.

Miller, Daniel, ed.

2005 Materiality. Durham, N.C.: Duke University Press.

Mitchell, Timothy

2002 Rule of Experts: Egypt, Techno-Politics, Modernity. Berkeley: University of California Press.

Mitchell, William J.

1996 City of Bits: Space, Place, and the Infobahn. Cambridge, Mass.: MIT Press.

Morris, Rosalind

2004 "Intimacy and Corruption in Thailand's Age of Transparency." In Off Stage/On

Display: Intimacy and Ethnography in the Age of Public Culture, edited by Andrew

Njihia, Mbugua

Shryock, 225-43. Stanford, Calif.: Stanford University Press.

2011 "MedAfrica." Lecture at the DEMO Conference, Santa Clara, Calif., September

Pamoja Trust

14. http://www.youtube.com/watch?v=Ts6Gn-KQgnk.

2009 “An Inventory of the Slums in Nairobi." http://old.sdinet.org/media/upload/ documents/Nairobi_slum_inventory_jan_09.pdf.

Poggiali, Lisa

n.d. "Digital Futures and Analog Pasts? Citizenship and Ethnicity in Techno-Utopian Kenya.” Unpublished manuscript.

Scott, James C.

1998 Seeing Like a State: How Certain Schemes to Improve the Human Condition Have Failed. New Haven, Conn.: Yale University Press.

Strathern, Marilyn

2000 “The Tyranny of Transparency." British Educational Research Journal 26, no. 3: 309-321. http://dx.doi.org/10.1080/713651562.

von Schnitzler, Antina

2013 "Traveling Technologies: Infrastructure, Ethical Regimes, and the Materiality of Politics in South Africa.” Cultural Anthropology 28, no. 4: 670-93. http:// dx.doi.org/10.1111/cuan. 12032 .

Weise, Karen

2014 “The Do-Good Startups of Nairobi.” Bloomberg Businessweek, December 29. http: / / www.businessweek.com/articles/2014-12-29/the-do-good-startups-ofnairobi.

West, Harry G., and Todd Sanders, eds.

2003 Transparency and Conspiracy: Ethnographies of Suspicion in the New World Order. Durham, N.C.: Duke University Press.

Winichakul, Thongchai

1994 Siam Mapped: A History of the Geo-Body of a Nation. Honolulu: University of Hawaii Press.

World Bank

1991 “Consultative Group for Kenya Paris, November 25 and 26, 1991: Chairman's Report of Proceedings.” Report no. 64570. http: / / documents.worldbank.org/ curated/en/932051468272358163/Consultative-Group-for-Kenya-Paris-

Zelaza, Tiyambe

November-25-and-26-1991-chairmans-report-of-proceedings.

1992 “The Colonial Labour System in Kenya." In An Economic History of Kenya, edited by William Robert Ochieng and Robert M. Maxon, 171-99. Nairobi: East African Educational Publishers. 